\title{
Atipik Kawasaki Hastalığı: Olgu Sunumu
}

\author{
Atypical Kawasaki Disease: A Case Report
}

\author{
Seher ERDOGAN ${ }^{1}$, Mehmet BOŞNAK ${ }^{1}$, Derya Aydın ŞAHİN ${ }^{2}$, Osman BAŞPINAR ${ }^{2}$ \\ 1. Gaziantep Üniversitesi Tıp Fakültesi, Çocuk Yoğun Bakım Bilim Dalı, Gaziantep, Türkiye \\ 1. Gaziantep Üniversitesi Tıp Fakültesi, Pediatrik Kardiyoloji Bilim Dalı, Gaziantep, Türkiye
}

\section{$\ddot{O Z Z E T}$}

Kawasaki hastalı̆̆ uzun süren ateş, pürülan olmayan konjunktivit, ă̆ız mukozasında inflamasyon, servikal lenfadenopati, el ve ayaklarda eritem, yaygin polimorf deri döküntüsü ile karakterize bir vaskülittir. En sık 6 ay-5 yaş arasında görülür. Kawasaki hastalığııın \% 7-10'u atipik seyirli olmaktadır. Tedavi edilmeyen olgularda \%15-25 oranında koroner arter anevrizmalarl, miyokard infarktüsü ve ani ölüm gibi kardiyak komplikasyonlar gelişebilir. Bu nedenle hastalığın erken teşhis edilmesi, intravenöz immünglobülin(IVIG) ve asetilsalisilik asit(ASA) ile tedaviye başlanması bu tür komplikasyonların gelişimini önlemek açısından önemlidir. Burada atipik Kawasaki hastaliğ tanısı alan ve tedaviye cevap veren olgu sunulmuştur.

Anahtar Kelimeler: kawasaki hastalı̆̆l; atipik kawasaki hastalığı; vaskülit

\section{ABSTRACT}

Kawasaki disease is an acute vasculitis that is characterized by prolonged fever, nonpurulent conjunctivitis, oral mucosal inflamation, cervical lympadenophaty, erythema of the hands and feet, and diffuse polymorphous skin rash. The most common age of occurence is between 6 months and 5 years. Coronary artery aneurysms may develop in \% 15-25 of untreated children and may lead to sudden death or myocard infarction. So early diagnosis and treatment with intravenous immunoglobulin and acetyl salicylic acid are important to prevent this complications. Here, we present a atypical Kawasaki disease, five year old case was treated on time and had no complication.

Keywords: kawasaki disease; atypical kawasaki disease; vasculitis

\footnotetext{
İletişim:

Sorumlu Yazar: Dr. Seher Erdoğan

Adres: Gaziantep Üniversitesi Tıp Fakültesi, Çocuk Yoğun Bakım Bilim Dalı, Gaziantep, Türkiye

Tel: +90 (342) 3606060

E-Posta: seher70@gmail.com

Makale Geliş: 27.10.2015

Makale Kabul: 06.03.2016

DOI: http://dx.doi.org/10.16948/zktb.34184
}

\section{GíRiş}

Kawasaki hastalığı kendini sınırlayan, sıklıkla infantları ve küçük çocukları etkileyen akut, febril multisistem bir vaskülittir. Cocukluk çağ1 vaskülitleri arasında Henöch-Schönlein purpurasından sonra ikinci sıklıkta görülür. Hastalık 1967'de Tomisaki Kawasaki tarafindan ateş, döküntü, konjunktivit, ellerde kızarıklik ve şişlik, boyunda lenfadenopati belirti ve bulguları olan çocuklarda tanımlanmıştır [1]. Kawasaki hastalığı Asya kökenlilerde, özellikle de Japonlarda daha sik olmak üzere tüm dünyada tanımlanmıştır. Çocuklarda akut eklem romatizması insidansının azalmasına karşılık, gelişmiş ülkelerde edinilmiş kalp hastalığı nedenleri arasında birinci sıraya yerleşmiştir. Henüz etiyolojisi ve patogenezi tam olarak aydınlatılamamıştır. Asya kökenlilerde hastalığın daha sık görülmesi genetik yatkınlığ mektedir. Tedavi edilmeyen olguların yaklaşık $\%$ 20-25'inde koroner arter anormalliklerinin gelișebilmesi hastalığın önemini göstermektedir. $\mathrm{Bu}$ komplikasyonların önlenebilmesi için erken tanı konulması, intravenöz immünglobülin ve yüksek doz asetilsalisilik asit tedavisinin erken dönemde başlanması gereklidir [2]. Bu olgu ile erken tanı konularak tedavi edilen ve kalp komplikasyonları önlenen olguyu sunarak, erken tanı ve tedavinin önemini vurgulamak istedik.

\section{OLGU SUNUMU}

5 yaşında kız hasta; 10 gündür devam eden ateş, vücutta döküntü, kaşıntı, halsizlik ve iştahsızlık yakınmaları ile hastanemize başvurdu. $\mathrm{Bu}$ yakınmalarla bir sağlık merkezine başvurduğu, üst solunum yolu enfeksiyonu tanısı ile antibiyotik ve antipiretik tedavi verildiği ancak yakınmalarının devam ettiği öğrenildi. Prenatal, natal ve postnatal öyküsünde bir özellik yoktu. Fizik muayenesinde; Ateş: $38.5^{\circ} \mathrm{C}$, Nabiz:140/ $\mathrm{dk}$, TA:90/60 mmHg idi. Genel durumu orta, bilinci açık, halsiz görünümde idi. Farinks hiperemikti. Bacaklarda ve gluteal bölgelerde daha belirgin olmak üzere tüm vücutta yaygın pembe, kaşıntılı maküler döküntüleri vardı. Bilateral konjunktivit ve beyaz çilek dili mevcuttu. 
Diğer sistem muayeneleri normal bulundu. Laboratuvar incelemesinde; Hemoglobin: $10.2 \mathrm{gr} / \mathrm{dl}$, Beyaz küre: 24.700/ $\mathrm{mm}^{3}$, Hematokrit: \%29, Trombosit say1s1: $216.000 / \mathrm{mm}^{3}$, periferik yaymada \% 75 nötrofil, \% 25 lenfosit vard1, toksik granülasyon yoktu, atipik hücre gözlenmedi. Sodyum: $127 \mathrm{meq} / \mathrm{l}$, Üre: $63 \mathrm{mg} /$ dl, Total protein: $5.1 \mathrm{gr} / \mathrm{dl}$, Albümin: $2.2 \mathrm{gr} / \mathrm{dl}$, Kreatin kinaz: $50 \mathrm{u} / 1$, Kreatin kinaz-MB: $32 \mathrm{u} / 1$, Laktik dehidrogenaz: $388 \mathrm{u} / 1$, C-reaktif protein: $21 \mathrm{mg} / \mathrm{dl}$, Sedimentasyon: $34 \mathrm{~mm} / \mathrm{h}$ idi, diğer biyokimyasal değerler normaldi. Bakılan Antinükleer Antikor, Anti-dsDNA, C-ANCA, P-ANCA negatif bulundu, C3 ve C4 normaldi. Kan ve idrar kültüründe üreme olmadı, boğaz kültüründe normal boğaz florası üredi. Elektrokardiyografide ritm sinüzaldi, patolojik bulgu yoktu. Bu bulgularla hastada Atipik Kawasaki Hastalığı olabileceği düşünüldü, yapılan ekokardiyografik incelemede (EKO); minimal mitral yetmezlik saptand. IV mayi ve antibiyotik tedavisi başlandı. Pediatrik kardiyoloji bölümünün önerisi ile IVIG infüzyonu (2 gr $/ \mathrm{kg}$ ) uyguland1. Ancak hastanın izleminde takipne gelişti, dinlemekle gallop ritmi duyuldu, hepatomegalisi saptand1. Tekrarlanan EKO'sunda sol ventrikülün dilate olduğu görüldü. Hasta yakın izlem amacıyla yoğun bakım ünitesine yatırıldı. 3.gün ateşinin devam etmesi üzerine IVIG infüzyonu tekrarland1. ASA $80 \mathrm{mg} / \mathrm{kg} /$ gün po başland1, Albümin $1 \mathrm{gr} / \mathrm{kg}$ IV verildi. Abdominal USG incelemesinde hepatosplenomegali ve minimal plevral efüzyon saptand1. Oksijen saturasyonunun 90 olması üzerine rezervuarlı maske ile oksijen desteği verildi. Hipotansiyon gelişmesi nedeniyle inotropik ajan başland1. EKG kontrolünde V4-V6'da daha belirgin olmak üzere tüm gögüs derivasyonlarında ST depresyonu ve T dalga negatifliği gözlendi, bakılan kontrol ProBNP: $35.000 \mathrm{pg} / \mathrm{ml}$, Troponin T: $0.027 \mathrm{ng} / \mathrm{ml}$, CK-MB: $47 \mathrm{u} / 1$ değerine yükseldiği görüldü. 2 gün sonra $E K G$ bulguları düzeldi, kardiyak enzimler normal düzeylere geriledi, ateși düştü, hipotansiyonunun düzelmesi üzerine inotrop desteği azaltılarak kesildi, oksijen gereksinimi kalmadı, ASA dozu $5 \mathrm{mg} / \mathrm{kg}$ ’a düşüldü.

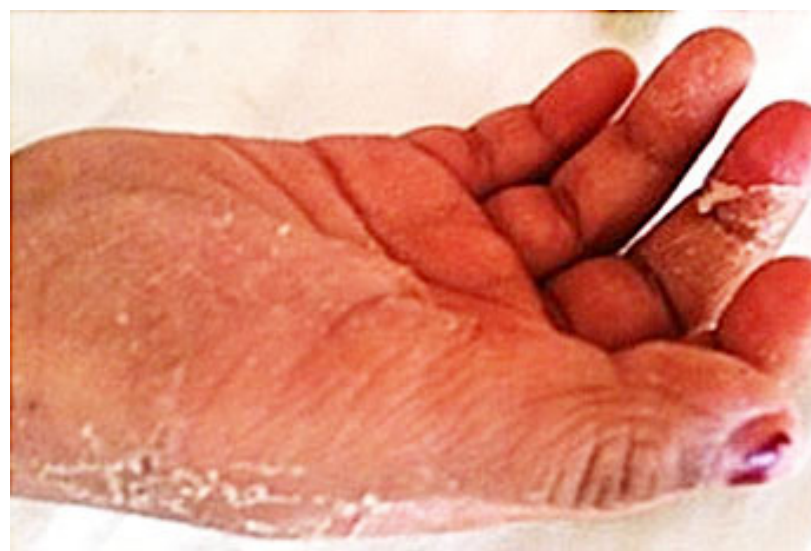

Resim 1. İzlemde ellerde soyulma görüldü.
Hastalığın 10.gününde ellerde soyulma gözlendi (Resim 1). Taburcu edilmeden önce yapilan EKO incelemesinde; sol ana koroner arterde fusiform anevrima tespit edildi (Resim 2), EF: \% 69 ölçüldü. Hasta ASA tedavisi verilerek kontrole gelmek üzere taburcu edildi.

\section{TARTIŞMA}

Kawasaki hastalığı en sik 6 ay ile 5 yaş arasında görülen sistemik bir vaskülit olup, gelişmiş ülkelerde çocuklardaki edinsel kalp hastalıklarının en önemli nedenidir. Hastalığın tanısı ateş, ekstremite periferindeki değişiklikler, polimorf ekzantem, bilateral konjunktival konjesyon, orofarenks mukozasındaki değişiklikler ve servikal lenfadenopatiden oluşan altı ana kriterden beşinin olması ile konulmaktadır [3]. Hastalığın altı ana semptomundan en sik görüleni ateştir. Beş günden uzun süren ateşin varlığında klinik bulguların üçünün saptanması ve diğer olas1 nedenlerin ekarte edilmesi durumunda atipik kawasaki hastalığından sözedilir. Atipik Kawasaki hastalığ daha fazla dikkat çekmektedir. Asıl sorun ise, bu vakaların sıklıkla yalnış veya geç tanı almalar1 ve tedavilerinin gecikmesidir [4]. Stockheim ve arkadaşlarının [5] retrospektif olarak derledikleri Kawasaki olgularında, klinik kriterleri tam sağlamayan ancak eşlik edebilen kusma, ishal, artralji, meningismus ve başağrısı gibi diğer bulguların daha ön planda olduğu olgularda gecikmenin olduğu belirtilmiştir. Çeşitli yayınlarda Kawasaki hastalığının \% 7-10'unun atipik şeklinde gözlendiği bildirilmiştir. Koroner arter anevrizma gelișme riskinin tipik Kawasaki hastalığ 1 kadar yüksek olması nedeniyle bu hastalarda da erken tanı ve tedavi önem kazanmaktadır [6]. Ekokardiyografik inceleme atipik hastalığın erken tanınmasında önemli rol oynar.

Kawasaki hastalığına eşlik edebilen diğer kardiyak patolojiler miyokardit, endokardit, hafif kapak yetersizlikleri ve perikardiyal efüzyondur. Son dönemlerde yapılan çalışmalarda KH'nın ateşli hastalıklardan ayırdedilmesinde

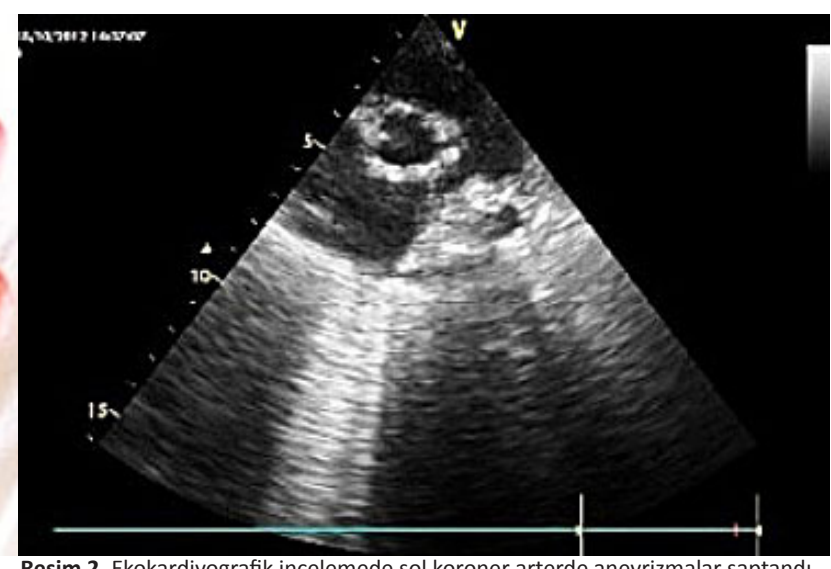

Resim 2. Ekokardiyografik incelemede sol koroner arterde anevrizmalar saptandı. $-21$ 
artmış BNP değerinin uygun bir parametre olabileceği üzerinde durulmaktadır [7]. Tanı kriterleri arasında olmayan, ancak Kawasaki hastalığı için oldukça spesifik bir bulgu da BCG aş1 yerinde eritem ve endurasyon olmasıdır. Diğer klinik bulgular arasında diyare, kusma, karın ağrısı, aseptik menenjit, artrit ve steril piüridir. Hastamızda Kawasaki hastalığ 1 tanı kriterleri arasinda yeralan servikal lenfadenopati bulgusu yoktu, yaklaşık 1 haftadır devam eden ateş, konjunktivit, yaygın maküler döküntü, beyaz çilek dili, farinks hiperemisi ile atipik kawasaki hastalığ1 düşünüldü.

Kawasaki hastalığında akut tedavinin amac1 akut inflamasyonu kontrol altına almak, uzun süreli sekelleri önlemek ve en önemlisi koroner arter duvarındaki inflamasyonu engellemektir. Standart tedavisi IVIG infüzyonu ( $2 \mathrm{gr} / \mathrm{kg}$ ) ve $80-100 \mathrm{mg} / \mathrm{kg} / \mathrm{gün}$ dört doza bölünmüş oral asetilsalisilik asit şeklindedir. Hasta üç-yedi gün ateșsiz kaldıktan sonra aspirin dozu idame tedavisi olan günde $3-5 \mathrm{mg} / \mathrm{kg}$ tek doza düşülür ve bu antiplatelet doza sedimentasyon ve CRP normal düzeye inene ve EKO'da anormallik saptanmayana kadar dört-altı hafta devam edilir.

Hastaların \% 10-15'inde bu standart tedavi uygulanmasına rağmen ateş devam edebilir veya tekrarlayabilir. Bu durumda birinci IVIG dozundan 48-72 saat sonra $2 \mathrm{gr} / \mathrm{kg}$ IVIG tedavisi uygulanmalıdır. Yine yanıt alınmazsa IV yüksek doz (30 mg/kg/gün 1-3 gün) steroid tedavisi önerilmektedir [8]. Hastalığın akut fazinda IL-6 ve tümör nekrozis faktör gibi sitokinlerin düzeylerinde artış olmaktadır [9]. $\mathrm{Bu}$ nedenle, dirençli olgularda TNFa'ya karșı monoklonal antikor, metotreksat, plazmaferez ve sitotoksik ajanların uygulanması ile ilgili çalışmalar yapılmaktadır. IVIG tedavisine rağmen dirençli ateş, düşük hemoglobin düzeyi, düşük albümin düzeyi, yüksek beyaz küre değerleri, yüksek CRP düzeyi, erkek cinsiyet ve bir yaşın altında olmak koroner arter anevrizma gelişimi için risk faktörü olarak kabul edilmektedir [10]. Demir ve arkadaşları [11] 2015'te yaptıkları çalışmada koroner arter lezyonu olan Kawasaki ve inkomplet Kawasaki hastalarında nötrofil/ lenfosit oranını yüksek bulduklarını, bu oranın 1, 32 ve üzerinde olmasinın koroner arter lezyon varlığı açısından iyi bir belirteç olduğunu belirttiler.

Sonuç olarak, döküntü ve antibiyotiğe yanıt vermeyen ateş ile gelen, miyokardit kliniği olan hastalarda, Kawasaki hastalığı ayırıcı tanılar içerisinde düşünülmeli ve komplikasyonların önlenebilmesi için erken tanı konularak tedavi başlanmalıdır.

\section{KAYNAKLAR}

1. Burns JC, Glode MP. Kawasaki syndrome. Lancet 2004;364:533-544.

2. Bostan ÖM. Kawasaki Hastaliğl. J Pediatr Inf 2011;5:46-50.

3. Cimaz R, Sundel R. Atypical and incomplete Kawasaki disease. Best Pract Res Clin Rheumatol 2009;23:689-97.

4. Kara A, Asal G, Tezer H, Devrim I, Cengiz AB, Yurdakök $K$, et al. Kawasaki hastalığ ve BCG reaktivasyonu:Bir vaka takdimi. Çocuk Sağlığı ve Hastalıkları Dergisi 2006;49:42-45.

5. Stockheim JA, Innocentini N, Shulman ST. Kawasaki disease in older children and adolescents. J Pediatr 2000; 137: 250-252.

6. Lin KH, Chang SS, Yu CW, Lin SC, Liu SC, Chao H, et al. Usefulness of natriuretic peptide for diagnosis of Kawasaki disease: a systematic review and meta-analysis. BMJ Open 2015;5.

7. Newburger JW, Takahashi M, Gerber MA et all. Diagnosisi, treatment, and long-term management of kawasaki disease: a statement for health professionals from the Committee on Rheumatic Fever, Endocarditis, and Kawasaki Disease, Council on Cardiovascular Disease in the Young American Heart Association. Pediatrics 2004; 114:1708-33.

8. Kobayashi T, Kobayashi T, Arakawa H. Prednisolone therapy for Kawasaki disease. Nihon Rinsho 2014;72:1623-8.

9. Takahashi K, Oharaseki T, Yokouchi Y, Naoe S, Saji T. Kawasaki disease: basic and pathological findings. Clin Exp Nephrol. 2013;17:690-3.

10. Koren G, Lavi S, Rose V, Rowe R. Kawasaki disease:review of risk factors for coronary aneurysms.J Pediatr 1986; 108:388-92.

11. Demir F, Karadeniz C, Özdemir R, Yozgat Y, Çelegen KKaraaslan $U$, et al. Usefulness of Neutrophil to Lymphocyte Ratio in Prediction of Coronary Artery Lesions in Patients with Kawasaki Disease. Balkan Med J 2015;32:371-6. 